\title{
Public Housing and the Poor: An Overview ${ }^{\dagger}$
}

\section{Lawrence M. Friedman*}

$\mathrm{P}$ UBLIC HoUSING became a reality in the United States only in the days of the New Deal. There were some gingerly steps toward public housing during the First World War, and a few more in the states in the Twenties, but a serious, living program had to wait for the days of the great depression. ${ }^{1}$ The major piece of federal legislation on housing was the Wagner-Steagall Act of $1937^{2}$ which, despite a gloss of amendments, remains on the statute books today, hardly altered in its basic design. On September 1, 1937, President Roosevelt signed the bill ${ }^{3}$ which was to begin a "new era in the economic and social life of America." Hopes ran high in the early years of the program. The wall of resistance to federally supported housing had been breached. A "real start" would be made "at last" toward "wiping out ... city slums." The states passed enabling legislation, local housing authorities were formed, and the flow of cash into public housing began in earnest. "In city after city," wrote Nathan Straus in 1939 , "the sound of the wrecker's hammer is heard, sites are being cleared, the excavators are at work, and the superstructures are going up . . . . [By] next summer . . . five thousand families will be moving from the slums into new and decent homes." In the years since then, public housing has become a familiar aspect of the urban landscape. By the end of 1965 every state had some public housing units in planning or operation, ${ }^{7}$ and

$\uparrow$ Some of the material on which this paper is based was gathered in the course of interviews. Some individuals who were interviewed would prefer not to be quoted directly. Some of the information supphed inust be treated as confidential. Consequently, supporting authorities for some statements have been omitted.

* B.A., 1948, J.D., 19551, LL.M., 1953, University of Chicago. Professor of Law, University of Wisconsin Law School.

1 On the forerunners of the Wagner-Steagall Act, see Fisher, Twenty Years of PunLic HousING (1959); a good short account is Riesenfeld \& Eastlund, Public Aid to Honsing and Land Redevelopment, 34 MIN. I. Rev. 610 (1950). On the Wagner-Steagall Act itself, see McDonneld, The Wagner Housing Act: A Case Study of the liegislative Process (1957).

250 Stat. 888 (1937), as amended, 42 U.S.C. $\$ \$ 1401-30$ (1964), as amended, 42 U.S.C. §§ 1402-21b (Supp. I, 1965).

3 N.Y. Times, Sept. 3, 1937, p. 1, col. 3.

4 Letter from Franklin D. Roosevelt to Nathan Straus, Administrator of the United States Housing Authority, March 17, 1938, quoted in Straus \& WEGG, HousnNo CoMas of AGE 189 (1938).

5 N.Y. Times, Sept. 3, 1937, p. 16, col. 3.

${ }^{6}$ Straus, Housing-A National Achievement, Atlantic Monthly, Feb. 1939, pp. 204, 210.

7 As of the end of 1963, Utah, Wyoming, and Iowa had no units of public housing. Houstng and Home Finafce Agency, Annual Report 306 n.1 (1963). Iowa since has passed enabling legislation. IowA CODE ANN. § 403A (Supp. 1964). At the end of 1964, every state had one or more local public housing authorities, except Oklahoma and this state had two 
more than 2,100,000 people lived in low-rent public liousing. ${ }^{8}$ In New York City more than half a million people lived in public housing units built with the aid of federal, state, or city money. ${ }^{9}$ The overwlielming majority of these units were products of the federal program. New York City had more public lousing than any other city; but every major city and a host of minor ones ran more or less substantial programs of their own. ${ }^{10}$ As of October 1964, 26,175 people lived in public lrousing in Detroit, Michigan; Duluth, Minnesota, at the end of 1964, operated three lrundred units divided into three separate projects. ${ }^{11}$ Whatever else these figures signified, they meant that vast tracts of slum wasteland had been cleared and that millions of people over the last thirty years had been rehoused in units which met at least minimum sanitary and spatial standards.

But to judge by some newspaper and magazine accounts-and even by the words of housing experts-the public housing program had betrayed its fond expectations. In 1937 Catherine Bauer, a highly respected expert on housing, praised the Wagner-Steagall Act as "progressive legislation"-a hopeful first step toward the goal of good housing for all. ${ }^{12}$ Twenty years later, in 1957, Miss Bauer returned to the subject in an article in Architectural Forum. The title was significant: "The Dreary Deadlock of Public Housing." 13 She found little to praise in the program as it had evolved. Rather, she saw rigidity and paternalism im management, crudity and segregation in project design, and a deplorable fragmentation of over-all housing policy. In the following issue of the magazine, eleven housing experts commented on her article and made suggestions for change. ${ }^{14}$ Not one of the eleven disagreed with her general thesis: that the public llousing movement was stagnant; that politically the program was at a standstill; that existing projects were badly conceived and perhaps did more harm than good; and that the whole program

projects federally owned and operated. Hodsing and Home Finance Agencx, ANNuAL Report 235, 239, Tables IV-1, TV-3 (1964).

8 Id. at 235.

${ }^{\ominus}$ New York City Housing Authority, Project Statistics 26, Dec. 31, 1964.

10 Every city of more than one million population ran a public housing authority aided housing program, and $89 \%$ (42 out of 47 ) of the cities of more than a quarter million and less than a million. Sixty-three per cent of the cities with more than fifty thousand and less than two hundred fifty thousand had programs. Housng and HoMe FINance Agencr, ANNUAL REPORT 240 (1964).

11 Information supplied by the respective housing authorities.

12 Now, at Last: Housing, New Republic, Sept. 8, 1937, pp. 119, 121.

13 Bauer, The Dreary Deadlock of Public Housing, Architectural Forum, May 1957, p. 140.

14 The Dreary Deadlock of Public Housing-How to Break It, Architectural Forum, June 1957, p. 139. 
needed radical reformation. This was the twentieth anniversary of the Wagner-Steagall Act.

It was a bad time for the image of public housing. Harrison Salisbury, Russian correspondent for the New York Times, came home to write his reactions to the domestic scene. What he saw in New York's housing projects profoundly shocked him-for example, the "stench of stale urine that pervades the elevators" in Fort Greene Houses, Brooklyn..$^{15} \mathrm{He}$ had other things to report about the "new ghettos," as lie called them. They were "human cesspools worse than those of yesterday."10 Fort Greene and similar projects were "monsters, devouring their residents, polluting the areas about them, spewing out a social excrescence which infects the whole of our society."17 The slums themselves had rarely felt sucli a tongue-lashing.

Salisbury's conclusions were published in book form and widely read. They were by no means the last such attack on public housing. Readers of the Chicago Daily News, in April 1965, were invited to share a sense of wrath and dismay toward public housing. A sensational series of articles excoriated the Robert R. Taylor homes, Chicago's "\$70 Million Ghetto." Taylor was the "world's biggest and most jam-packed housing development," an "all-Negro city within a city," a "civic monument to misery, bungling and a leellish way of life," a " 'death trap,' a concentration camp." Its tenants-who sometimes called their lome "the Congo Hilton" -lived im misery, "grappling with violence and vandalism, fear and suspicion, teen-age terror and adult chaos, rage, resentment, official regimenting." 18 In the same year, a tenant of the Syracuse Housing Authority described her home as "nothing but a prison camp." In Syracuse, under the impetus of the war against poverty, the INegro poor organized to do battle with those they identified as their oppressors. Prominent among these oppressors were officials of the local housing authority. To judge by the outcry, public lousing in Syracuse was also worse than the slums. ${ }^{10}$

Public housing does not totally lack defenders, but they lave spoken softly of late. It is hard to think of any prominent lousing fignre outside of government who defends the program as it is. Politically, the program lias little appeal. Appropriations for additional units have been grudgingly voted in Congress; time and time again requests have been scaled down. What is perliaps more significant, authorizations have often gone begging

16 SalisbURy, The Shook-Up Generation 74 (1958).

16 Id. at 75 .

17 Id. at 77 .

18 Chicago Daily News, April 10, 1965, p. 1, col. 1.

19 The tenant quotes are from The Tenants Report, Public Housing: Syracuse Style, This Is the Way It Is, 1965. Materials on the Syracuse novement were supplied to me by Professor Warren C. Haggstrom of Syracuse University. 
because local government agencies have not been interested in applying for federal grants-authorized units have "washed away."20 This is perhaps the darkest synnptom of all: A prograin must be genuinely unpopular if free federal money is spurned. The unpopularity of public housing need not be left to oblique inference. In scores of cities and small towns, public housing has been put to the test by the voters. Where it is legally possible, opponents have demanded referenda on the question. In a distressing number of cases, bond issues to finance the program have failed or public housing has been voted out of town. ${ }^{21}$

Where does the trouble lie? Is it in the conception, the shape of the public housing prograin? Is it in its mode of administration? Perhaps the problems lie in both. The indictment is clear: Public housing, ostensibly designed to clear the slums and to alleviate the sufferings of the poor, has failed to do either. We turn now to the facts.

I

THE PUBLIC HOUSING PROGRAM: CONCEPTION AND DESIGN

The public housing law is one of a vagnely defined group of statutes called "social" or "welfare" legislation.

It would be a mistake to suppose (if anyone did) that the WagnerSteagall Act ${ }^{22}$ arose solely out of a gradual persuasion of decent-minded people that the sluns were odious, crowded, and evil, and that the federal governinent had a duty to reheve the sufferings of the poor. The social and economic conditions in the slums provided the opportunity, the background, and inuch of the emotive power of the law. Yet reformers had long dreamed in vain of public housing. And the slums were surely no worse than they had been in the nineteenth century, though possibly they were larger.

In 1937 the country was suffering from a deep and dangerous depression. Fully one-quarter of the work force was unemployed during the worst days of the depression. In the spring of 1933, thirteen to fifteen million were unemployed. ${ }^{23}$ Millions of families were barely making a living. The number of "poor people" in the country liad been vastly increased; indeed, many of the "poor people" were formerly members of the middle class, wlio had enjoyed prosperity in the twenties. They retained their middle-class culture and their outlook, their articulateness, their

20 Seligman, The Enduring Shums, in The Exproding Metroporrs 92, 105 (1958).

21 E.g., in elections in April and June 1961, Rapid City, South Dakota, and Marin County, California, turned down low-rent proposals. 18 J. of Housing 289 (1961).

2250 Stat. 888 (1937), as amended, 42 U.S.C. $\$ \S 1401-30$ (1964), as amended, 42 U.S.C.

$\S \S$ 1402-21b (Supp. I, 1965).

23 Brown, Public RetIeF 1929-1939, at 65 (1940). 
habit of expressing their desires at the polls. There were, therefore, millions of candidates for public housing who did not belong (as later was true) to the class of the "problem poor"; rather they were members of what we might call the submerged middle class. The attractiveness of public housing was enormously enhanced because the potential clientele was itself enormous, composed of millions of relatively articulate citizens, angry and dispirited at their unjust descent into poverty. Public housing was not supported by the dregs of society; a discontented army of men and women of high demands and high expectations stood ready to insist on decent housing from government or at least stood ready to approve and defend it. The political climate was receptive to federal planning and federal housing-not so much as a matter of radical ideology, but out of a demand for positive programs to eliminate the "undeserved" privations of the unaccustomed poor.

Moreover, business was stagnant in the thirties. Programs of social welfare and relief were tested by their ability to create new jobs and prime the business pump as much as by their inleerent welfare virtues. Public works programs were exceedingly popular for this reason. ${ }^{24} \mathrm{~A}$ vast federal program of house building naturally received the enthusiastic support of manufacturers of building supplies and workers in the building trades. The normal opposition to "socialized" housing made its appearance in debate, ${ }^{25}$ but it was weak and somewhat muted. Nonetheless, business support for the act was conditioned upon the act being so structured as to avoid any actual government competition with business. Homes would be built only for those who could not possibly afford to buy them on their own. A clear wall must separate the public and the private sector. This too was only partly ideological. Government, it was felt, should not cut into the markets of private industry; it must stimulate fresh demand and make fresl jobs-otherwise the effect of the program on the economy would be wasted.

During the depression, the volume of private housing construction was very low. In 1925, 900,000 llousing units were constructed; in 1934, only $60,000 .{ }^{26}$ Yet in one sense no housing shortage developed. During much of the depression, plenty of apartments stood vacant. ${ }^{27}$ People who were poor doubled up with relatives, lived in "Hoovervilles" and shanties, returned to rural areas, and in general failed to consume the housing supply. Rents were extremely low. The ligh vacancy rate posed a potential danger for

24 Mitchell, Depression Decade 314-38 (1947).

25 E.g., 81 Cong. REc. 8079 (1937) (remarks of Senator Walsh).

26 Brooktngs Instifution, THe Recovery Problem in the Untted States 183-84 (1936).

27 Id. at 184-85. 
the program. If public construction increased the housing supply during a period in which many dwellings stood vacant, rents would decrease still more and vacancies would increase. In a decade willing to kill baby pigs and impose acreage controls on farmers, one could hardly expect to see government flooding the loousing market with new units. And in fact, the Wagner-Steagall Act was careful to avoid the problem of over-supply. No units were to be built without destroying "dwellings ... substantially equal in number to the number of newly constructed dwellings provided by the project." ${ }^{28}$ This provision - the so-called "equivalent elimination" provi$\operatorname{sion}^{20}$-killed two birds with one stone. It neutralized potential opposition from landlords and the lousing industry by removing the danger of oversupply; at the same time, by making slum clearance a part of the law, it appealed to those wliose desire for public lousing stemmed from their loathing of the slums and slum conditions. The Wagner-Steagall Act was thus shaped by the force of concrete social conditions; what emerged was a program geared to the needs of the submerged middle class, tied to slum clearance, and purged of any element of possible competition with business. ${ }^{30}$

Constitutional difficulties played a part in determining one of the most notable features of the program-its decentralization. From 1933 on, the Public Works Administration had run its own public housing program. ${ }^{31}$ In 1935 a federal district court case lield that the federal government liad no power under the constitution to clear land and build public housing. It was not proper, said the court, for the federal government "to construct buildings in a state for the purpose of selling or leasing them to private citizens for occupancy as hoines."32 The federal government never appealed this decision. In 1935 the government's prospect of sympathetic treatment by the United States Supreme Court seemed bleak; attempting to overturn the adverse housing decision might risk the whole program of public works. On the other hand, no important legal barriers stood in the

2850 Stat. 891 (1937), as amended, 42 U.S.C. $\$ 1410$ (a) (1964), as amended, 42 U.S.C. $\S 1410$ (a) (Supp. I, 1965).

29 Robinson \& Altman, Equivalent Elimination Agreements in Public Housing Projects, 22 B.U.L. REv. 375, 376 (1942).

30 The 1949 act, to make the point crystal clear, provided that no annual contribution contract be entered into unless the local agency demonstrates "that a gap of at least 20 per centum ... has been left between the upper rental limits for admission to the proposed lowrent housing and the lowest rents at which private enterprise unaided by public subsidy is providing . . . decent . . . housing." 63 Stat. 422 (1949), as amended, 42 U.S.C. $\$ 1415$ (7) (b) (ii) (1964).

31 Fisher, Twenty Years of Public HousIng 82-89 (1959).

32 United States v. Certain Lands, 9 F. Supp. 137, 141 (W.D. Ky.), aff'd, 78 F.2d 684 (6th Cir.), dismissed, 294 U.S. 735 (1935), 297 U.S. 726 (1936). See also United States v. Certain Lands, 12 F. Supp. 345 (E.D. Mich. 1935). 
way of a decentralized program. Washington could supply money and a certain amount of benign control; title to property and the motive force in condemnation could remain vested in local public agencies. A key New York state decision strengthened this view, distinguishing the federal cases as inapplicable to state power. ${ }^{33}$ Moreover, decentralization was politically attractive to those who dreaded further expansion of the "federal octopus."

Financial considerations had an important impact on the design of the lousing law. If the federal governinent had made outriglt grants to local authorities to build houses, immense amounts of money would have been immediately required. Under the act, however, local authorities were invited to borrow money through bond issues; with the proceeds, they were to acquire sites, clear them, and put up houses. The federal government would enter into "contracts" with local housing authorities, under which the federal government would agree to make annual contributions for a long period of time. The federal govermnent would pay (in essence) enough money for the interest on the bonds and the amortization of the principal. Operating expenses for the housing projects would come out of current rents. In this way, federal contributions would be kept relatively small; housing could be built on the installment plan, and paid for over a period of fifty or sixty years. ${ }^{34}$

Note, too, that the tenants were only partially subsidized. They were not given "free" housing. Each tenant had to pay his rent. Project rents had to be sufficient to pay operating costs-maintenance, administration, and payments in lieu of taxes to local government for fire and police protection and other municipal services. ${ }^{35}$ Though the federal act was discreetly silent on the subject, the rent requirement meant that the unemployed and the paupers were not welcome in public housing. They could not pay the rent, any more than in private housing. There are "some people," said Senator Wagner, "who we cannot possibly reach; I mean those who have no means to pay the rent. ... [0]bviousily this bill cannot provide housing for those who cannot pay the rent minus the subsidy allowed." 38 The projects were for poor but honest workers-the members of the submerged middle class, biding their time until the day when they regained their rightful income level. The tenants were not to receive any "charity." The difference between a dole and a subsidy is psychologically powerful, whether or not the distinction is good economics. The working

${ }^{83}$ New York Housing Authority v. Muller, 270 N.Y. 333, I N.E.2d 152 (1936).

8450 Stat. 892 (1937), as amended, 42 U.S.C. $\$ \$ 1410$ (b), (c) (1964), as amended, 42 U.S.C. § 1410(c) (Supp. I, 1965).

85 The so-called "in-lieu" payments. See 63 Stat. 428 (1949), as amended, 42 U.S.C. $\S 1410$ (h) (1964), as amended, 42 U.S.C. $\$ 1410$ (h) (Supp. I, 1965).

8681 Cong. Rec. 8099 (Aug. 3, 1937). 
class residents of public housing were not to receive a gift from the government, but their rightful due as citizens. Public housing, arguably, was no more "charitable" than the free land of the homestead act of 1862 -an earher form of middle-class subsidy. Decent, samitary apartments were a stepping-stone to a fee sinple cottage-the American dream. Perhaps a radical fringe of housing reformers looked on pubhic housing as something more fundamentally "public"; but the core of support lay in an old and conservative tradition.

If this general analysis is correct, what would happen to public housing if a rising standard of hiving released the submerged middle class from dependence on government shelter? Public housing would be inherited by the permanent poor. The empty rooms would pass to those who had at first been disdained-the unemployed, "problem" families, those from broken hoines. The program could adapt only with difficulty to its new conditions, because it had been originally designed for a different clientele. To suit the programs to the needs of the new tenant would require fresh legislation; and yet change would be difficult to enact and to implement precisely because the new clientele would be so poor, so powerless, so inarticulate. The pohtical attractiveness of public housing would dimimish. Maladaptations to reality in the program would disenchant housing reformers; they would declare the program a failure and abandon it to search out fresh cures for bad housing and slums.

All this is precisely what has happened, as a brief sketch of the history. of public housing since 1937 will illustrate. The first public housing projects were, in general, low-rise rowhouses; they blended in fairly well with their surroundings. Some of them, outside the major cities, were "suburban" in location and design. The residents were members of the submerged middle class, and the projects were literally stepping-stones to middle-class life and a liome of one's own. We may take as an archetype of the stepping-stone project Middletown Gardens, in Delaware County, Indiana-a "112-unit low-rent housing community built on an 80-acre outlying tract: 15 acres im houses, 33 in gardens, 7 a recreation grove, 4 a ball field, 21 untouched timber." ${ }^{\text {37 }}$ Here, according to a report in 1944, one-quarter of the families were able to save enough money to buy their own homes. ${ }^{38}$ Of course, rising incomes helped. But only the subinerged middle class partook of the benefits of rising incomes.

The outbreak of war interrupted the progress of pubhic housing. Housing construction had to be suspended during the emergency, except where it served some wartime purpose. As early as June 1940, when the

$371 \mathrm{~J}$. of HousING 47 (1944).

882 J. OR Housirg 9 (1945). 
war was still a distant thunder, Congress passed a defense housing act ${ }^{80}$ which provided for construction of units for workers. Under this act, contracts with local housing authorities could be revised and low-income units diverted to defense housing. The Wagner-Steagall Act was then only three years old. Moreover, when victory was in sight, the emphasis in construction changed from defense to veterans' housing. Construction of veterans' housing began in earnest at the end of the war. ${ }^{40}$ During the war, conditions underlying the housing market were fundamentally altered. No longer was there a housing surplus, together with a surplus of the honorable poor. Private building completely halted during the war; defense factories soaked up all the employables and put high wages in peoples' pockets. The result was a stupendous housing shortage-the supply of housing remained constant while the demand multiplied inordinately. This demand would have driven rents to fabulous levels, except for stringent national controls on rents and evictions.

The end of the war was traumatic in one regard: It threatened to bring to a close a period of prosperity-prosperity which was doubly welcoine because of the long depression it replaced. No one wanted war, but no one wanted poverty either. Clearly, a high level of construction was one guarantee against depression; and government had to be prepared to give subsidies, prime pumps, and do whatever was pohitically necessary to keep construction healthy and high. The beneficiaries of the new housing programs were the veterans and the middle class generally. Prosperity meant an end of concentrated pohtical demand for minimum housing built in the city for the submerged middle class. The major need now was for veterans' houses, individually owned and detached from those of their neighbors. This was the only new program appealing both to homeowners and builders. To keep land costs down, any such mass development had to be outside of town. Thus began the suburban housing boom, financed by vast infusions of public money. The inoney was paid, however, in the form of subsidy, aid to private enterprise, mortgage insurance, and tax breaks. It was never "charity." Moreover, a hittle public inoney went a very long way. Meanwhile, old-style public housing languished.

30 54 Stat. 681 (1940), as amended, 42 U.S.C. $\$ \$ 1501-05$ (1964). Later in the same year the Lanham Act was passed making further provisions for defense housing. 54 Stat. 681 (1940), as amended, 42 U.S.C. \$§ 1521-23, 1541-50 (1964).

40 An Act of June 23, 1945, amended the Lanham Act to authorize the Housing Administrator to use his powers to "provide housing for distressed families of servicemen and for veterans and their families." 59 Stat. 260 (1945), as amended, 42 U.S.C. $\$ \S 1571-73$ (1964). A Joint Resolution of December 31, 1945, appropriated $\$ 160,000,000$ to be used for these purposes. 59 Stat. 674 (1945), as amended, 42 U.S.C. $\S 1572$ (1964). In 1946 a "Veterans' Emergency Housing Act" was passed. Act of May 22, 1946, ch. 268, 60 Stat. 207. See also Robinson \& Robinson, State Spending for Veterans Housing, 1949 WIs. L. REv. 10 (1949). 
Worse than that: Public lousing was now boxed in, in the core of the cities. Outlying sites, on the fringes of the metropolitan areas, where land was raw and cheap, were no longer available; this land was de facto reserved for veterans' subdivisions. Public housing was losing its best sites -and its best clientele. The submerged middle class moved out as fast as it reasonably could. Indeed, those who would have liked to stay were not given the option; they were simply thrown out. After the war, comfortable tenants who enjoyed their subsidized homes frequently wanted to continue where they were. But the most they could achieve was a measure of delay. Their struggle against eviction from public housing lad to be abandoned. ${ }^{41}$ Pressure built up to force people to give up subsidized apartments and buy subsidized homes instead. The economy (it was thought) depended on the health of the suburban building boom; the nation could not afford to let people with good incomes go on living with New Deal subsidies. The sharp, bitter struggle over evictions was not a struggle of rich against poor. It was a struggle between middle-class veterans and defense workers, on the one liand, and business interests on the other. The scale tipped in favor of business presumably because of the strong general interest in a healthy level of construction. The dispossessed veterans were (in part) paid off by subsidized mortgages and a whole host of government programs which eased the journey to the suburbs. ${ }^{42}$ Public housing, meanwhile, was relegated to the permanent poor in the city, and to the new urban immigrants. In the big cities, these were chiefly Negroes from the South. ${ }^{43}$ The compromise of the late 1940's and early 1950's meant reinforcement of the notion that public housing was exclusively for those who were certainly, indisputably, and irreversibly poor..$^{44}$

But this development meant that the political strength of public lousing had eroded and would continue to erode. The new tenants were precisely those who had the least power in our society, the least potent voice in the councils of city hall. The middle-class masses, moreover, were spending their sweat and treasure in a wild flight from the slums and their residents. Now that they had attamed the status of suburban property owners, they had no intention of giving up their property values and their hard-won status by allowing their former neighbors (and even less de-

41 See FPHA Opens Drive for Removal of High-Income Families, 4 J. OF HoUSING 143 (1947) ; 7 J. of HousING 27 (1950).

42 See generally Beyer, Hodsing: A Factual Analysis 126-28, 237-46 (1958).

43 On the postwar movement of Negroes, see generally TaEUber \& TaEuber, NeGroes iN Citres (1965).

44 It was in 1949 that federal law first insisted that public housing agencies not "discriminate against families ... [whlose] incomes are derived in whole or in part from public assistance ..." 63 Stat. 422 (1949), as amended, 42 U.S.C. $§ 1415$ (1964), as amended, 42 U.S.C. § 1415 (Supp. I, 1965). 
sirable people) to move in. The slums were not to follow them into the suburbs. Race and income prejudice was by no means confined to the suburbs. It flourished in the city, too, particularly in the little enclaves of frame houses that formed ethnically homogeneous, proud, and selfcontained neighborhoods. These sub-cities would also resist public housing in their midst. Public housing no longer meant homes for less fortunate friends and neighbors, but rather, intrusions of "foreigners," the problem poor and those least welcome "forbidden neighbors," the lower class Negro. Public housing not only lost its pohtical appeal but what was left of the program was confined to the core of the city. Public housing remained tied to slum clearance and rebuilding out of necessity. The suburbs and the middle-class areas of the city had shut their doors. Vacant land could not be used for sites unless the land happened to he in skid row or a Negro neighborhood. ${ }^{45}$

Land in the core of the city was far more expensive than the raw land of the suburbs. City land had to be bought, cleared of commercial and residential properties, and then redeveloped. Labor and material costs were high and kept rismg. So did the buildings. The cost squeeze meant the end of low-rise, "home-style" housing projects. The buildings turned into towers-six-story, ten-story, then nineteen, twenty or more in New York and Chicago. ${ }^{46}$ Costs and the enmity of the outside world squeezed the buildings into the heart of the slums. The ratio of Negroes to whites increased radically. ${ }^{47}$ The whites streamed out. By the early 1950's, project managers had to learn to cope with "problem" families. The texture of hife in the projects changed for the worse; since more delinquent families lived in them, they were the locus for more and more delinquency. The attention of the public was now directed to public housing not as a hopeful program of reform but as the site of public folly and private decay-vandahism, crime, and unrest. The sordid facts of life in public housing merely reinforced the passionate resistance of the rest of the city to public housing projects. Who wanted such places in their neighborhood? It was a vicious circle. And when the intellectual community looked out of its own windows and saw the projects in the distance-drab, ugly blocks of cement standing like soldiers-when they observed that public housing built glettos for Negroes and the despondent classes, they, too, called for

45 See the now classic study of Chicago's site location problems, MEyerson \& BANFIFid, Politics, Planntag and the Public Interest (1955).

46 For a description of the beginnings of this process, see Riley, Cost Reductions Pioneered in New York Public Housing, 5 J. or HousIng 105, 106 (1948).

47 By the end of June 1963, almost $96 \%$ of the occupants of public lousing in Washington were Negro. WEAVER, THE URBAN COMAPLEX 251 (1964). Since 1955 Negroes bave been in the majority in St. Louis' public lousing. Information supplied by the St. Louis Housing Authority. 
a halt. Right and left wings, oddly enough, agreed that the program had outlived its utility; both called for a curtailment of fresh building. ${ }^{48}$ Some have even urged the abandonment of existing projects, and Charles Abrams has called it a fiction that "public housing must be owned by the city forever," ${ }^{\prime 49}$ a fiction which, if hived by, would result in public housing becoming the "concentrated retreats" of the "saddest and bitterest assemblage of mortals ever permitted a foothold on earth."

Ironically, the same forces that have crippled public housing have made possible the one briglit exception to the "dreary deadlock": housing for the elderly. In many cities today the only public housing being built is housing for the elderly. The Wagner-Steagall Act of 1937 said nothing about old people; but in the last decade, the law has increasingly favored the elderly. The trend began inodestly enough im 1956, when, for the first time, public housing was opened up to unmarried people (not members of a "family") who were sixty-five years of age or more. ${ }^{51}$ In the 1960's much more positive inducements have been offered. The 1961 act offered a subsidy of up to 120 dollars per unit occupied by "senior citizens," where such assistance was necessary to operate these units in the black. ${ }^{52}$ In this regard, federal law has merely mirrored local opinion. Milwaukee, for example-a city notoriously hostile to public housing-has eagerly embraced housing for the elderly. ${ }^{53}$ In Chicago, 5,661 units were under construction as of June 30,$1964 ; 4,345$ of these were reserved for the elderly. ${ }^{54}$ And Marin County, California, three years after defeating a public housing proposal, voted overwhelmingly to support a proposed 200-unit development for the elderly. ${ }^{55}$ In $1964,52.6$ per cent of the new umits placed under contract "were to be designed specifically for the elderly."

\footnotetext{
48 It is no surprise that a conservative like Milton Friedman would favor a cash subsidy to poor people over the erection of public housing. Frtapman, CAPITAIISM and Freedom 178 (1962). This proposal has points in common with the proposals for rent certificates or subsidies which are now so much in favor with housing "liberals," and specifically in that the plans contemplate abandonment of the program of building higli-rise "projects." For a discussion of income subsidies, see WeNDT, Hodsing PoLrcy-THE SEARcE for Soldtions 217-25 (1963); The Dreary Deadlock of Public Housing-How to Break It, Architectural Forum, June 1957, p. 139.

49 Abrams, The City Is the Frontier 37 (1965).

$50 I d$. at 38.

5170 Stat. 1104 (1956), as amended, 42 U.S.C. $\$ 1402$ (2) (1964), as amended, 42 U.S.C. $\S 1402$ (2) (Supp. I, 1965).

62 See generally Spector, Housing for Senior Citizens, 11 N.Y.L.F. 30 (1965).

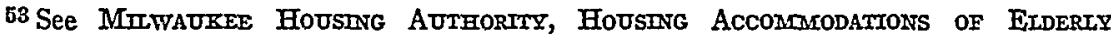
Persons IN THE CITY of MIITAUKEe (1958).

54 Chicago Housing Authority, Fact Sheets, Table 3, June 30, 1964.

65 21 J. OF HoUSING 513 (1964).

68 Housing and Home Finance Agency, ANndat Report 235 (1964).
} 
It is easy to see why housing for the elderly is succeeding where public lousing in general has failed. Housing for the elderly taps the only remaining reservoir of poor people who are also white, orderly, and middleclass in behavior. Neighborhoods which will not tolerate a ten-story tower packed with Negro mothers on AFDC might tolerate a tower of sweet but impoverished old folks. Old people are never vandals; they do not whore and carouse. Many of them are honest working-class people caught in a trap set by low retirement incomes, small pensions, inadequate savings, and high medical bills. Furthermore, lousing for the elderly helps solve a problem all too common for middle-class people-what to do with aged, dependent parents. Subsidized housing for the grandparents is a solution to many people's troubles. Moreover, the old people are more likely than the problem poor to be grateful, docile, and unseen. ${ }^{57}$

\section{II}

ADMINISTRATION OF PUBLIC HOUSING

In the preceding section of this paper, we have sketched the history of public housing and advanced the thesis that the program was designed originally for the submerged middle class. That class no longer needs or wants public housing, except in the special cases of the elderly and the handicapped. Public housing has been imherited by the dependent poor and by the low-income urban Negro, and as a result, the program has become less popular politically. This unpopularity in turn has adversely affected the design of the program. We shall now briefly look at some aspects of the administration of public housing, as it has been affected by the change in clientele, and as it affects the welfare of the post-war tenants. ${ }^{.8}$

When public housing was conceived of as subsidized shelter for members of the submerged middle class, it did not call for modes of administration different from those which any ordinary landlord would be called upon to use. Housing was run on a business-hike basis. Tenants were expected to pay their rent, and pay it promptly. The pages of the Journal of Housing are full of accounts of successful managers who achieved one hundred per cent rental payments-sometimes through the use of tough methods. In Buffalo, it was reported in 1945 that managers "competed"

67 Similarly, special favors have been accorded in recent years to public housing for the handicapped. See, e.g., 73 Stat. 667 (1959), as amended, 12 U.S.C. \& 1701 (q) (1964), as amended, 12 U.S.C. \$ 1701 (q) (Supp. I, 1965).

58 Good general assessments can be found in ScHorr, Stums aNd Sociad INSEcurtTy 85-93 (1964); Mulvihill, Problems in the Management of Public Housing, 35 TEMr. L.Q. 163 (1962). 
for one hundred per cent rent collections; some managers "attach the three-day [eviction] notice to the tenant's door, for public view."59

In the early 1950's, housing officials began giving voice to uneasiness at the change in character of their tenants. Managers and loousing officials worried out loud about the large number of "problem families" moving into their buildings. ${ }^{60} \mathrm{Mrs}$. Bette Jenkins of Detroit, writing in the Journal of Housing in 1951, thought that projects had a duty to accept problem families; but even sle wondered whether there was "some danger that public housing might become labeled as a catchall for all the people who do not tend to make satisfactory personal judgments." ${ }^{311}$ Some less tenderhearted officials began to strengthen discipline. In 1956, for example, the New York City Housing Authority announced a "get tough" policy to get rid of families that could not control delinquent children. ${ }^{62}$ Other projects tried injecting massive doses of paternalism, in an effort to cure rather than to kill. Public housing, in the opinion of most lousing officials, had

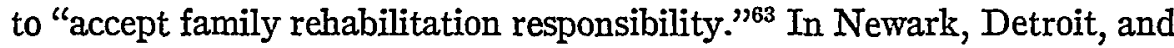
Nashville, management tried to use social workers, tenant relations experts, or other devices to help "problem families" adjust. ${ }^{64}$ Problem famihes have remained a problem. The change in the clientele of public housing has continued until the present time, except insofar as housing for the elderly alters the picture. In many cities, it is not unusual if more than a third of the tenants derive all their income from welfare checks; and in individual projects the percentage may run higlier. ${ }^{65}$ Naturally, under these circumstances public housing becomes more "institutional." Public housing is more than shelter; it also provides a place for golden-age clubs and well-baby clinics. ${ }^{68}$ In Chicago, housing projects have their own public

592 J. of Housing 79 (1945). See also 3 J. of Houszng 154 (1946) (Philadelphia); $4 \mathrm{~J}$. of Housing 49, 50 (1947) ("hard-boiled" tactics in Wilmington, North Carolina and in New Orleans).

Bo See, e.g., How Much "Selection" Should There Be in Public Housing Tenant Selection? Four Answers, 8 J. of Housing 91 (1951); Aronov, The Problem Family, 11 J. of Housnsg 425 (1954).

01 Jenkins, "Problem Families"-New Answer to Their Housing Eligibility Status, $8 \mathrm{~J}$. of HousLe 283 (1951).

02 N.Y. Times, Jan. 31, 1956, p. 23, col. 5.

63 Filker, Public Housing Management Must Accept Family Rehabilitation Responsibility, $13 \mathrm{~J}$. OF HOUSJng 168 (1956).

0414 J. of Housing 131 (1957) (Detroit); 15 J. of Housing 13 (1958) (Newark); 12 J. of Houstre 188 (1955) (Nashville).

65 In Chicago in 1964, 2,067 out of 4,345 families in the Taylor homes and 1,965 out of 3,597 Aid for Families of Dependent Children in the Cabrini-Green project received some form of government assistance. 1,736 families in Taylor were on AFDC. Chicago Housing Authority, Fact Sheets, Table 9, 1964.

${ }^{6 B}$ See, e.g., Welcome to Your Home 17-18 (undated), a pamphlet of The Baltimore Urban Renewal and Housing Agency, listing "the Men's Club, the Women's Sewing Club, 
assistance offices, located right on the premises, with the case load drawn exclusively from the project. Many large projects have enough young children to fill their own elementary school, which may also be located right on the grounds. Housing managers and their staff workers can easily communicate with teachers and social workers; public housing can be nore highly "administered" and nore paternal and institutional. The size and design of the projects, as well as the homogeneity of the tenants, encourages this response to conditions.

What has become of the administration of public housing as the type of resident has changed? What kind of rules are made and enforced? What kind of programs are carried out? In order to answer these questions, tenant selection will be briefly discussed followed by a slightly more detailed account of tenure and eviction. Consideration of these points will suggest some propositions about public housing administration that may have wider implications.

\section{A. Tenant Selection}

Tenant eligibility is determined by statute and local rule. Federal law makes relatively few demands on administration, insisting only that only poor persons be allowed in public housing. The Wagner-Steagall Act ${ }^{07}$ limited tenancy to "families of low income" who could not "afford to pay enough to cause private enterprise in their locality ... to build an adequate supply of decent, safe, and sanitary dwellings for their use." Income limits were part of the federal law- the Act was restricted to families "whose net income at the time of admission does not exceed five times the rental." Between 1949 and 1961, the federal statute specifically stated that public housing agencies were not to "discrimmate against families, otherwise eligible for admission to [public] housing, because their incomes are derived in whole or in part from pubhic assistance." "Federal law also asks local agencies to adopt admission policies which "give full consideration" to their "responsibility for the rehousing of displaced families, - to the applicant's status as a serviceman or veteran," his age, disability, housing

the Golden Age Club, the Mothers' Club ... classes in Home Nursing, Nutrition, or First Aid ... Boy Scouts, Girl Scouts, Y-Teens . . . a recreation program ... Well Baby Clinics...."

0750 Stat. 888 (1937), as amended, 42 U.S.C. $\$ 1402$ (2) (1964), as amended, 42 U.S.C. $\S 1402$ (2) (Supp. I, 1965).

0850 Stat. 888 (1937), as amended, 42 U.S.C. $\$ 1402$ (1964), as amended, 42 U.S.C. \$ 1402 (Supp. I, 1965). For families with three or more minor dependents, the ratio was six to one. In 1958 specific income-rent ratios were dropped from the statute, leaving the matter to the discretion of local authorities and state statutes; the federal statute still required that families be "of low income," however. 73 Stat. 680 (1959), as amended, 42 U.S.C. § 1402 (1964), as amended, 42 U.S.C. \$ 1402 (Supp. I, 1965).

69 Act of July 15, 1949, § 301, 63 Stat. 422. 
conditions, and urgency of housing need. ${ }^{70}$ Other than this, federal law is silent on eligibility for public housing; and indeed, the statute offers little guidance as to the administration of projects or the termination of tenancy. ${ }^{71}$ In the 1950's, during the palmy days of McCarthyism, the so-called "Gwinn amendment" briefly made nonmembership in subversive organizations a condition of tenancy. ${ }^{72}$ The Gwinn amendment reminds us of the possibility that onerous conditions for eligibility can be written into federal law. On the other hand, the hife of the Gwinn amendment was short and the reaction of courts quite hostile. ${ }^{73}$ The experiment has not been repeated.

State laws are not much more explicit than federal law. The states have followed the federal lead in prescribing income himits. More than thirty states have the five-to-one ratio or some variant; ${ }^{74}$ a few have a different ratio, or a flexible maximum coupled with a general requirement of poverty; a few simply delegate authority to local projects to fix rent scales. ${ }^{75}$ Some states specifically provide for the problem of the over-income tenant; in New Jersey, for example, he may continue to occupy his quarters until his income is more than twenty-five per cent over the maximum for entry. ${ }^{70} \mathrm{~A}$ few states add a detail here or there-by spelling out their preference for veterans, for example. ${ }^{77}$ But in the main, tenant selection is controlled by the housing authorities themselves. Some of them have their own preference hsts-giving special place or exemption from some prerequisite to veterans, to persons in desperate need of housing, or even to students. ${ }^{78}$

The selection process lias not been carefully studied. If there were abuses, no one in government seemed to have heard of them. Within categories of preference, selection is made on a first-come-first-served basis, although screening out of "undesirables" is often practiced with the aid of social workers. If responsible officials discriminated among applicants there would be no machinery for correcting these abuses. We may be fairly

7050 Stat. 891 (1937), as amended, 42 U.S.C. \& 1410(g)(2) (1964), as amended, 42 U.S.C. \& 1410 (g) (2) (Supp. I, 1965).

71 See 50 Stat. 891 (1937), as amended, 42 U.S.C. $\$ 1410(\mathrm{~g})(3)$ (1964), as amended, 42 U.S.C. \& 1410 (g) (3) (Supp. I, 1965).

72 Act of July $31,1953,8101,67$ Stat. 307.

78 See, e.g., Lawson v. Housing Authority, 270 Wis. 269, 70 N.W.2d 605 (1955).

74 E.g., NEb. Rev. Stat. 14-1422 (1962).

76 N.Y. PUB. HousINg \& 156 (six-to-one ratio); LA. Rev. StaTs. $\S 40: 478$ (1960) (no specific ratio, but a general requirement of "Iow income" and a list of factors to be considered); Mont. Rev. Codes ANN. \& 35-103(18) (1961) ("low income" to be determined by local authority).

70 N.J. Stats. ANN. § 55:14H-20 (1964).

77 E.g., NEv. REv. STaT. § 315-510.

78 San Francisco waives a one-year residency requirement for students. San Francisco Housing Authority, Low-Rent Housing-Policy, Part I, sec. I, p. 3 (rev. Feb. 1964). 
confident that "discrimination" in the usual sense does not occur. One cannot think of any reasons offhand why officials should play favorites. Applicants are too poor to offer much of a bribe. A class difference separates officials from apphicants; a project manager is highly unlikely to have a cousin or sister-in-law anxious to be moved from the bottom to the top of the waiting list. This, indeed, is a general characteristic of welfare administration, as opposed to, for example, the enforcement of housing codes or the administration of regulatory programs that affect businessmen. The selection process is therefore likely to be fair, in the sense of conforming to general rules, and will remain fair in this sense even though applicants have no "rights" and no meaningful review. But though fair, selection may be blind, rule-bound, and unwilling to temper principle to the dictates of common sense. Recently complaints that filtered through legal aid services and agencies of the War on Poverty have brought some examples to light. One housing authority, for example, tried to evict two Puerto Rican brothers, seventeen and eighteen years old, after their mother died and left them orphaned, on the grounds that the authority could not enter into a lease with minors. ${ }^{79}$ The Housing Authority of New Bern, North Carolina, adopted a rule which called for the eviction of any tenant to whom "additional illegitimate children" were born during tenancy. ${ }^{80}$ Perhaps many additional injustices are hidden in the criteria of selection or in the manner in which screeners work and perceive their work. These injustices, however, are not easily cured. What reform calls for here is not enforceinent of rules, but changes in rules. And that in turn requires political pressures upon management-a theme to which we shall return.

Race discrimination was not unknown in the early days of public housing; indeed, the Public Housing Authority deliberately encouraged segregation in some cities. ${ }^{81}$ Race discrimination has been abandoned as policy by the PHA; race is no longer officially a criterion for eligibility ${ }^{82}$

79 I am indebted to Edward V. Sparer, Legal Director, Center on Social Welfare Policy and Law, of Columbia University Scliool of Social Work, for this example, drawn from a paper, The Poor Man's Lawyer and Governmental Agencies, delivered by Mr. Sparer to the National Conference on Law and Poverty, sponsored by the Department of Justice and the Office of Economic Opportunity, June 24, 1965, at Washington, D.C.

80 The legality of this rule is currently being tested. $-\mathrm{I}$ am indebted to Mr. Sparer for this example, too.

81 E.g., in San Diego, see Davis \& McEnTIRe, Residince AND Rnce 320 (1960). In fairness to PHA, it ouglit to be pointed out that public housing accommodations were generally available to Negroes "in accordance with need . . . in striking contrast to the discriminatory distribution of local, state and Federal funds," and that it was white prejudice that defeated many attempts by housing officials to break out of the ghetto. WEAver, The NeGro GHetTo 179 (1948).

82 For the PHA regulation, promulgated during the Kennedy administration, sec 24 C.F.R. $\$ 1500.6$ (1963). 
or assignment to a project. Many Southern projects are still totally segregated. For example, there are seven projects in Anniston, Alabama-three all-white and four all-Negro ${ }^{83}$ And there is a great deal of de facto segregation in public lousing in the North. It is as distasteful to Negroes as de facto school segregation. The remedies are if anything more elusive. In many cities, a majority of public tenants are Negroes. This is true in Chicago, for example. Chicago has virtually no all-white lousing projects; but it has many all-Negro projects; and in some projects the percentage of white tenants is far greater than the percentage of whites in public housing in general. ${ }^{84}$ Spreading the few white tenants equally througlout the city would simply drive many of them out of public lousing, without benefiting the Negro particularly. Yet the present pattern is one of $d e$ facto segregation. Public housing is, by and large, located in Negro areas and is inhabited by Negroes. Projects are so large in the major urban areas that a project would be impossible for a white, middle-class community to digest, if some giant liand picked it up and transported it to the urban fringe. We have seen how political and social forces have transformed public lousing into Negro gletto housing. De facto segregation illustrates quite the opposite point from tenant selection. Here, the granting of formal riglits to Negroes to demand desegregated projects would be meamingless in many cities, not because no real abuses exist, but because the problem is so basic that only a radical solution can remedy the matter; rights are not enougl.

\section{B. Tenure and Eviction}

Once a family las moved into public lousing, it becomes subject to rules regarding tenure and eviction. As is true of eligibility and selection, these rules are largely local. Simce federal law, state statutes, and local rules all agree that only the poor may live in public lousing, a tenant is liable to lose his right to stay if lis income exceeds the maximum set for the particular project. ${ }^{85}$ In addition, however, his tenure is jeopardized if he misbehaves or breaches the terms of his lease. Misconduct may bring down upon him a variety of sanctions-fines, withholding of privileges, eviction. Eviction is the ultimate and major sanction of the authority, and the only one susceptible currently to any measurement. We slall, therefore, confine our discussion to the legal position of the tenant with regard to eviction.

\footnotetext{
83 Home and Housing Finance Agency, Low Rent Project Directory, June 30, 1965, p. 38.

84 In Chicago in 1964, whites were a tiny minority of the families in public housing $(2,472$ out of 29,386$)$; yet in one project of 139 families, there were no Negroes at all. Figures taken from Chicago Housing Authority, Racial Occupancy as of June 30, 1964, Table 12 (unciated mimeo).

${ }^{85}$ In practice, there is considerable administrative leeway.
} 
The tenant has virtually no protection against eviction. His lease is rigged against him, and his tenancy is on a month-to-month basis. Leases for a year, or two years, which are common for tenants in private buildings, are unknown in public housing. Nothing in any state statute requires a short-term lease explicitly; yet there is probably no lousing authority in the country which regularly grants more than a month-to-month lease to its tenants. ${ }^{86}$ On thirty days' notice then, any public lousing tenant in the country can lose his rights to his home.

Does a llousing authority need a reason for eviction, or may it avail itself of the privilege of the sliort-term lease? This question lias been more frequently litigated than any other issue of landlord-tenant riglits in public lousing, although there are few reported cases. Project managers are apt to be aware of the reported or unreported test case in their community, and what it decided. This is true in Milwaukee and Chicago ${ }^{87}$ In general, housing authorities have insisted that they do not need to assign any reasons for termination; they insist that they may evict at the end of the inonth's term by coniplying with the general landlord-tenant statuteslike any other landlord whose tenants hold under a nionth-to-month lease. The courts have usually agreed with the landlords. ${ }^{88}$ One fairly recent New York case held the housing authority to a somewliat higher standard and was willing to hold that an eviction was not "reasonable." But this holding is quite exceptional. Other cases-including several in New York ${ }^{00}$ -have upheld the authority's view of the law. It does not nuch inatter whether the authority's right to evict is absolute, or whether it must at least coniply with its own regular procedures. In either event, the tenure of residents in public housing is as precarious as that of any slum-dweller -perhaps more so.

Evictions are probably not common in any housing project, ${ }^{01}$ even if

\footnotetext{
${ }^{86}$ An examination of leases from more than thirty housing authorities, in big cities and little ones, and from every part of the country, confirms this.

87 In Chicago, the case is Chicago Housing Authority v. Ivory, 341 Ill. App. 282, 93 N.E.2d 386 (1950); see 7 J. of Housivg 432 (1950). For reports of other cases, see 6 J. of Housing 150 (1949); 11 J. of Housnng 278 (1954); 21 J. OF HousLng 384 (1961).

88 E.g., Walton v. City of Phoenix, 69 Ariz. 26, 208 P.2d 309 (1949).

${ }^{89}$ Sanders v. Cruise, 10 Misc. 2d 533, 173 N.Y.S.2d 871 (Sup. Ct. 1958).

90 E.g., Smalls v. White Plains Housing Authority, 34 Misc. 2d 949, 230 N.Y.S.2d 106 (Sup. Ct. 1962).

91 In Minneapolis, with 2,462 dwelling units, forty-eight families were asked to leave in the fiscal year ending September 30, 1964. Twelve of these were "commumity problems" (misconduct). Letter from V. E. Dale, Director of Management, Housing and Redevelopment Authority, Minneapolis, Aug. 12, 1965. Public housing in Minneapolis is predominantly white and more than one half of the units are for the elderly. But in the same period St. Louis (largely Negro, nonelderly) had only eighty-one involuntary move-outs of "undesirable tenants," out of a low-rent population of more than 25,000. St. Louis Housing Authority, Move-Out Study (undated mimeo).
} 
we consider tenants as "evicted" if they are asked to leave and they comply without court order. The threat of eviction, however, may be a meaningful and potent sanction even if it rarely has to be carried out. ${ }^{92}$ The reported cases suggest that some authorities are anxious to rid themselves of troublemakers. In one case, the tenant's children were a nuisance. ${ }^{93}$ In another, a member of the family was alleged to be a dope addict. ${ }^{94}$ In another, the head of the family was in jail. ${ }^{95}$ There is a continued search for the submerged middle class, that lost legion whose ghost still haunts the program. And, to be sure, the safety and happiness of all may depend upon getting rid of the few. No one denies that management needs the right to protect the other tenants and the property by eliminating people who destroy the walls or the peace of their neighbors. But even the fragmentary evidence of the cases raises disquieting doubts whether management has restricted itself to clear-cut cases of gross misconduct.

There are similar doubts in regard to rule-making powers. Authorities may evict without reason; in addition, and in consequence, they have very broad powers to impose rules and regulations upon the tenants-provided only that the rules are not illegal or so scandalous as to arouse rebellion. Again, many rules and regulations are perfectly salutary and indeed necessary. But others are debatable. It would be a rare housing project, for example, which permitted dogs in high-rise buildings. Half a million people in New York City must choose between subsidy and pets. Bills are regularly introduced into the legislature to let tenants have their cats and dogs, but the housing authority has beaten back every attempt. ${ }^{96}$ The New Orleans housing authority allowed seemg-eye dogs for blind tenants only after considerable hullabaloo. ${ }^{97}$ Normally, management can be quite stiffnecked toward its constituency, and its view of "the good of the project" is unassailable.

92 The San Francisco Housing Authority "has never had to evict for over-income or misconduct. Many thirty-day lease cancellation notices have been served for the two latter reasons, however. The families moved prior to the necessity of taking final action." Letter from Fred S. Threefoot, Manager, Rental Office, San Francisco Housing Authority, Aug. 19, 1965.

${ }^{03}$ Smalls v. White Plains Housing Authority, 34 Misc. 2d 949, 230 N.Y.S.2d 106 (Sup. Ct. 1962).

${ }^{94}$ Sanders v. Cruise, 10 Misc. 2d 533, 173 N.X.S.2d 871 (Sup. Ct. 1958).

95 New York City Housing Authority v. Watson, 27 Misc. 2d 618, 207 N.X.S.2d 920 (Sup. Ct. 1960).

90 N.Y. Times, March 25, 1964, p. 35, col. 4; see "Man's Best Friend" Is Cause for Eviction, 6 J. or HousING 150 (1949), reporting an eviction in Stockton, California, in 1948, for ownership of a dog. In most cities, the lease or tenants' handbook specifically forbids pets. Goldfish and canaries are sometimes expressly exempted (e.g., in Bayonne, New Jersey). The housing authority of Kansas City, Kansas, feels called upon specifically to outlaw chickens and ducks as well as the usual dogs and cats.

97 I am indebted to Professor Jacobus tenBroek for this information. 


\section{Control of Management Behavior}

Since management is formally free to do more or less as it wishes, what limits can be placed upon its power? Judicial review is a natural answer for a lawyer. Judicial review-indeed, administrative review—of the ruleinaking and rule-enforcing power of the housing authorities is virtually nonexistent. Yet one must liesitate to ask for more. There is no reason to believe that judicial review would amount to more than an insistence on elementary (and empty) form. Since the authorities have secured for themselves formal freedom to evict without reasons, there is no formal impediment to governance by informal rules. Nothing requires the authorities in most cities to promulgate definite regulations which the tenants must follow. Of course, most authorities do publish either formal rules or landbooks and guides which embody rules and regulations. Rules also appear in the leases, though in that form it is doubtful if they are read. The problem is not secret rules, since management is not insane: It wants its rules to be known and to be followed. The problem is what the rules say and who decides them. It is liard to believe that the courts are either willing or able to run the housing authorities. They might require the authority to comply with certain rule-making procedures, but they are not likely to care what the rules say. ${ }^{98}$

Nor are judges likely to be more enlightened than the average man on problems of the poor. In an eviction case, the Supreme Court of Westchester County, New York, reminded petitioner that "the [Housing] Authority is composed of public-spirited citizens serving without compensation," who acted in ways thought "necessary for the administration of the project and the welfare of all of the tenants," and thus not lightly to be altered. ${ }^{99}$ There is an implication that the petitioming tenant was both presumptuous and ungrateful. Sucl an attitude holds little promise of gain for dissatisfied tenants.

How much can we expect from the tenants themselves? Tenants are "organized" in many projects, but for welfare or social purposes, not to run anything which management considers important. Activist tenant organizations may have existed and flourished to a greater degree in some of the early projects. In those days, the projects were crowded with members of the submerged middle class; and anong these were people who were politically active and anxious to form tenant organizations. Indeed, Harrison Salisbury claims that bureaucratic management helped stamp out tenant organizations, because left-wing activists among the tenants

98 See Handler, Controlling Official Behavior in Welfare Administration, this Symposium.

99 Smalls v. White Plains Housing Authority, 34 Misc. 2d 949, 951, 230 N.Y.S.2d 106, 109 (Sup. Ct. 1962). 
proved to be too much of an annoyance. ${ }^{100}$ The passage of the Gwinn amendment suggests that there might be some substance to this charge. But in any event, the change in chentele of public housing, from the submerged middle class to the dependent poor, would in itself explain a decrease in group participation among tenants. The normal state of mind in public housing may be one of apathetic detachment. ${ }^{101}$ And the officially approved state of mind for the dependent poor is a combination of shuffling servility and childish zest for arts and crafts.

Quite another sort of tenant organization has arisen recently. The Syracuse tenant organization can be taken as symptomatic of a latter-day unrest. This organization bitterly objects to certain of the rules imposed upon tenants by management. For example, they complain that management assesses unfair fines and penalties. Tenants have claimed that they must pay for broken windows, whether they themselves caused the breakage or not. And alongside their specific complaints goes a more general one: that they have no power or voice in the management. They demand "a voice and a vote." "102

Is there sufficient evidence to judge whether the unrest at Syracuse arises because the housing administrators there are unusually harsh, or obtuse, or simply that the tenants are uncommonly restless? When residents of Chicago's Taylor homes call their project worse than the slums and use the nickname "Congo Hilton," are we hearing the voice of most tenants, a few tenants, or all tenants? Are we hearing a protest against a particular style of management, against management in general, or against conditions in society in general? Our lack of knowledge is itself an important point. The tremendous leeway of management has the legal and social result of plunging management practices into the deepest obscurity. This lessens the extent to which the outside community can exert its influence. And the outside community has not been interested. As far as the public lias been concerned, public housing projects (like mental hospitals and prisons) are warehouses where the poor can be stored and ignored. The literature on the management of public housing is nonexistent-a hiterature of silence. Managers write hints to each other in the trade journals; Washington advises and consents from above. An outside appraisal has been almost totally absent. The tremendous polemic literature over public housing has to do with the way projects look-the

100 Sactsbury, The Shook-Up GeNeration 81 (1958).

101 But at least one observer has analyzed a wide variety of "types" among slum and public housing dwellers. Salzman, Redevelopment Effectiveness Contingent on Understanding Shum Occupants, 13 J. OF Housing 289 (1956).

102 The Tenants' Report, supra note 19. For one study of attitudes of tenants, see Hollingshead \& Regler, Attitudes Toward Slums and Public Housing in Puerto Rico, in Tre Urban Condtrton 229-45 (Duhl ed. 1963). 
aesthetics of the projects, which means nothing or almost nothing to the residents ${ }^{103}$-and with the misbehavior of the tenants, not with misbehavior toward them. The recent polemic literature tends to conclude, as one writer neatly put it, that the tenants are the "same bunch of bastards"104 they were before they moved in. It follows somehow that public housing is a failure and ought to be replaced. That the projects are misguided or mismanaged in operation rather than in conception is a possibility rarely considered. That meamingful reforms may be possible within present projects must at least be weighed as a chance before being rejected. Can society, or the tenants, control and improve public housing-as it is, not as it might be?

\section{Management Styles}

It is common to confuse the possibility of abuse with actual abuse. Custom, sentiment, and social forces are potent curbs on behavior even when no formal rule binds. We must be hesitant, therefore, in ascribing evils to all public housing management, even though there are few formal limits on management behavior. For one thing, there is no one style of management. The projects themselves are too different for one style of management. There are two polar types of project. One is the institutional, high-rise ghetto, largely inhabited by poor Negroes in the big city and characterized by a higl number of "problem" families. Then there are communities of the submerged middle class-projects for the elderly, and low-rise, low-key projects in smaller communities or on the fringes of metropohtan areas (many of them built in the early days of public lousing). Clearly, the two types call for-and must get-different styles of unanagement.

Project managers have considerable administrative discretion. Projects are relatively autonounous administrative units. This too makes for a great deal of variation in governing public housing. A Chicago manager reports that he does not follow the policy of expelling over-income tenants. $\mathrm{He}$ "goes along" with his high-paid tenants for a year or even two. These are "good" tenants and he does not want to lose them. If he waits long enough,

103 This point is hardly susceptible of proof, and many learned men swear to the contrary, for example, Lewis Mumford, who is sure that esthetic degradation in the modern city has vast, evil consequences: "[N]ever before in recorded history" have people "lived in such a savagely deteriorated environment, ugly in form, debased in content." It is hard to deny the indictment, which he adroitly subjoins to a catalog of the undoubted harm to health which arises out of slums. Yet many people live lives of agony in slum buildings which were once gorgeous mansions, and the rich too live often in vulgar, ugly-but comfortablebuildings. Is the poor child who grows up in Florence or Venice ahead of the child of "Coketown"? MUMFord, The CITY IN History 466-74 (1961).

104 Seligman, The Enduring Shms, in Tye Explodmig Metropours 92, 106 (1958). 
the income limit at the project may be raised; or the tenant may lose his job. In any event, this manager evicts as few over-income tenants as he possibly. can. The same manager regards "quarter parties" (parties at which admission is charged, usually a quarter, and drinks and sandwiches sold at a quarter apiece) as grounds for summary expulsion. Some managers in Milwaukee, on the other hand, have never heard of this practice; but they take a more stringent view of over-income tenants. Intensive study would no doubt reveal further variations. Administration variation can be enormous, even when separate administrators are governed by the same formal rules; and variation can be small even though no formal rules bind administrators. The same is true of the management of public housing. As if through some giant conspiracy, all public housing projects force their tenants to sign a month-to-month lease. The universal use of a month-to-month lease is an example of a consistency of practice which is not required by formal law. Practice in regard to over-income tenants shows variations in administration, on the other hand, though formal law seems to require uniformity. Attitudes of management toward misconduct and eviction show still another pattern. Here it is the absence of formal rule that permits management practices to vary.

Variations in management style are probably related to the type of project. The conscientious manager of a Negro ghetto is naturally eager to keep well-behaved tenants who set a good example; he is loathe to evict them if their income goes up. The manager of a "middle-class" project has no need for good examples; his role is to provide subsidized shelter for people who are temporarily earming less than they could and should; or for the elderly whose income does not fluctuate. Variations of this sort between types of project are understandable, and, to a large degree, justified. There may be other variations which are less justified but which reinain locked away from prying eyes.

One source of difficulty is that the goals of public housing have never been agreed upon, even by those who strongly support the program - even perhaps within the minds of many housing officials or project managers. Is it the duty of public housing to provide a subsidized, sheltered home for the respectable, unfortunate poor? This is probably the predominant goal of housing for the elderly. Is it the duty of public housing to provide minimum facilities for the poor-to protect them from fire and rat bites, and incidentally, to protect the city from the spread of fire and infection? Or is it the duty of public lousing to rehabilitate the dependent poor, by providing them with a total new environment and a massive infusion of social services?

These three goals are to a degree incompatible. They certainly cannot coexist in one project; they imply different rules, strategies, and modes of 
management. Housing for the submerged middle class can be and perhaps should be run in the same way that a major private landlord runs his apartment house. On the other hand, these projects are not private; they are run by government einployees, and they are not subject to the discipline of a competitive market. There is no reason why "middle-class" public housing, including housing for the elderly, should not give its tenants a full battery of legal rights, long-term leases if anybody wants thein, a strong tenant voice in project affairs not as a matter of administrative grace, but of right, and tenure froin eviction except for cause established by reasonable rules concurred in by tenants. We might even insist that internal procedures be judicialized to a degree. It is hard to think of any legitinate prerogative or duty of administration which would be harmed by adding some procedural and substantive restraints. On the other hand, it is precisely in these projects that abuse of discretion is least likely to occur and is least likely to endanger the prerogatives of tenants.

Projects inhabited by the dependent poor present much more difficult questions. The present state of affairs is certainly not ideal. The monthto-month lease is umecessary and ought to be eliminated. Its value lies in the broad discretion it affords to housing administrators. Administrative discretion may be a good thing under many circunstances, but only if flexibility serves some real function; there is no reason to insulate managers completely froin responsibility and embarrassment through the device of a short-term lease. And no device should be neglected that might increase the stake of the poor in their homes, their communities, and in their circle of neighbors.

Do we conceive of housing projects for the dependent poor as custodial? Or do we think of them as providing an environment within which society can attempt to rework wasted hives and untie the knots of decadence? These competing goals may imply competing rules of government. A custodial project may be as hard and orderly as a prison; but it might also be run on easy-going permissive terms. To create a total environment, however, a certain amount of discipline is essential-discipline to prevent tenants froin living in terror, discipline to create a climate of order which is a prerequisite for rehabilitation. Those who wish to reform public housing - particularly those who complain that the projects are ugly, grim enclaves, shut off froin the community-frequently suggest scattering pocket-size projects about town, and even insinuating a subsidized tenant or two into private housing. ${ }^{105}$ One can readily agree that

105 This is the theory that underlies one form of "rent subsidy," which las long been a favorite of authorities on housing. E.g., Brown, PUBLIC HousnNG IN ACTION: THE REcord of PITTSBURga 88 (1959). The 1965 housing law authorized a limited program of rent subsidies and also a program of leasing space in private housing by local pubhic authorities. 79 Stat. 451, 
in the long run, the solution to the social ills of the Negro ghetto must include breaking down the walls that separate the poor Negro from his white neighbors. But in the short run, and within slum commumities, a sheltered enclave is a vital prerequisite for the offering of massive social services to public housing tenants. Teachers and social workers should be able to walk unafraid on the grounds at least by daylight. There should be space for playgrounds and meeting rooms. If existing communities are destroyed by private building or by civic projects, public lousing can at least provide a stable locale where the community could possibly be rebuilt. The isolation of the projects may be, in absolute terms, an evil; but the most radical causative factors producing that isolation arise out of political forces which condemn public housing to internal exile and higlrise life. These forces, at least in the short run, are not likely to be overcome.

These remarks must not be taken as an endorsement of the present system of building high-rise, segregated housing in the core of a city for those who cannot afford better housing. Practically everyone agrees that "vest-pocket" projects, mixed-income projects, and the insinuation of the poor into middle-class neiglıborhoods througl rent subsidies and similar programs is far better than the present system. I would entirely agree. Others msist that tenants wlose incomes rise slould be allowed to buy their apartments or at least stay on and exert their good influence on their neighbors. But the danger of all these programs is that they are likely to benefit only the members of the submerged middle class. Who will be selected to hive in the middle-income building? No doubt a tenant who can "pass" for middle class. Once again, we may be propounding solutions which subsidize and encourage all but the rock-bottom poor. A Utopian vision of the future should not be used to liann the helpless of today.

Since the huge, evil barracks are likely to be with us for many years, how shall we govern them? Once it is agreed that a certain amount of disciphine, rules, order, and police is necessary in public liousing for the poor, we can address ourselves to the difficult task of finding a level of disciphne as consistent as possible with admimistrative requirements, the rehabilitative goal, and the wishes and needs of the tenants. Undoubtedly, we could do with less "management" and less rules. It would be good to see more debate on issues of pohicy-and on smaller questions, too. Is there really no way to let tenants have pets? It is so easy to forbid petsa stroke of the pen will do it. It is not quite so easy to calculate the costs

12 U.S.C. $\$ 1701$ (s) (Supp. I, 1965). The rent subsidy program was concerned mainly with encouraging new business construction; it was not funded in 1965 and attempts to appropriate a paltry amount for the program were barely succeeding as of early May 1966 despite the most strenuous Administration efforts. 
and the benefits of cats and dogs and to try to devise some method of letting tenants have their pets without harming the project. It is probably. correct to assume that hard-core slum projects cannot govern themselves as smoothly and easily as "middle-class" projects. But surely the answer is not to deny any rights-formal or informal-to tenants. Internal procedures should, perhaps, be formalized, if only to enhance the self-respect and dignity of some of the tenants. In general, ways should be sought to make tenants feel more of a stake in a place which, after all, and despite its defects, is their home and which is in theory run for their benefit, not the benefit of the government. Equally important, perhaps, is a need for outside, independent controls over management-not legal controls, necessarily, but the kind of disciphned control which public opinion imposes on issues and institutions which arouse articulate inembers of the middle class to nag at their public servants. If the poor cannot nag by themselves, somebody must do it for them-lawyers, perhaps; latter-day reformers of the Jane Addams stamp; professors, if they can be induced to interest themselves; politicians of the opposition party.

The militancy of the poor is a new factor in the situation. It is an easy, and safe, prediction that attacks on the mode of management of public housing will increase as time goes on. The rumblings out of Syracuse and elsewhere are ominous and revealing. Yet in another sense these rumblings are a sign of great hope. The militancy of the poor-particularly the Negro poor-has a tremendous potential for bringing about social reform. In one sense, it is almost the only hope for administrative overhaul; the other champions of the tenants are fickle and sporadic. In the long run, the ills of public housing are not going to be cured by administrative reform or by giving tenants "rights" which they cannot use or are untramed to use. In the long run the only solution is to break down the ghetto walls and win acceptance for the Negro poor in the general society. This means, then, that the solution must be political. But when the tenants orgamize and make demands, and assault the prerogatives of management, they are seeking a political solution; and thus, paradoxically, the achievement of useless rights may turn out to be useful, since what will have happened will have been a shift in the balance of power. And power is the matter at stake, not formality. ${ }^{106}$

Not that there are no dangers in militancy. Angry cliques of tenants, though we may (and must) trust them to measure their own self-interest,

106 When a tenant organization sues to have a rule or practice of an authority declared "unconstitutional," this may be as much an attempt at a political solution as trying to get a law passed would be. The act of vindicating riglits is often the act of creating rights. Appeal to the courts is an appeal to another power-granting or power-ratifying authority in our society. Though new rights created througl legal action may have (in some theoretical sense) "always existed," for practical purposes they were unborn, not dormant. 
cannot be expected to diagnose the ills of the system perfectly, since no one else can. And so we are likely to hear complaints against managers that are nnjustified, or reflect nnavoidable conditions, or which are simply unreasonable. But if we are willing to let people govern themselves, we must be willing to let them commit the unreasonable in their lives. Still, the Negro poor are a minority. For any minority, life in a democracy is a process of striking workable bargains with the majority; and the majority is white. The whites must feel that the costs of resistance to Negro pressures are not worth the aunoyance of civil disorder; that segregation bears too high a price, that the comfortable old order of rule and of despotism (benevolent and otherwise) is no longer feasible. The militancy of the poor demonstrates to the others how high the price really is; but militancy is most effective when it appears to be strong but self-controlled, principled but ready to bargain. Otherwise, opposition sees no alternative to continued resistance. In the case of public housing, it is neither honest nor desirable to clamp down the hid on rebellious tenants (even when action is taken "for their own good"); the hikely result is simply more angry frustration-even if we were sure (which we are not) that we knew what is good for other men.

In any dispute between tenants and managers, the outside public will control, if it wishes. The general community is woefully ignorant of public housing; it ought to know more. It must realize that many of the ills of public housing are caused by conditions insisted upon by the very people who criticize the outcome. Moreover, doubts ought to be resolved on the side of the tenants: This the community must understand. Public lousing is meaningless or hypocritical if it is not an effective vehicle to make better the life of the poor. That is the object, or ought to be; management is only an instrument. Bureaucratic convemience and paternahism are not the point of public housing; they are perversions. Much of the fault for present ills can be found in the long shadow of history, as this paper las attempted to show. But the program is not incurable. What is needed, quite simply; is more subtle flexibility, in fitting the means to the ends. 